\title{
Complementary medicine
}

SIR - Complementary and alternative medicines are more popular than ever before. A recent Australian survey suggests that about half of the general population employs such treatments ${ }^{1}$. This is remarkable when we know so little about the effica-

damage such as spinal cord transection and 1 disk protrusion.

Such survey data are inevitably limited. The first questionnaire was likely to be completed by relatively healthy proponents of CAM and not by individuals with experi-

\begin{tabular}{|c|c|c|c|c|c|}
\hline \multicolumn{6}{|c|}{ SUSPECTED ADVERSE EFFECTS OF COMPLEMENTARY/ALTERNATIVE MEDICINE } \\
\hline & \multicolumn{2}{|c|}{ Users survey } & \multicolumn{3}{|c|}{ GP survey } \\
\hline Therapy & $\begin{array}{l}\text { \% Report- } \\
\text { ing AEs }\end{array}$ & $\begin{array}{l}\text { Most commonly } \\
\text { reported AEs }\end{array}$ & $\begin{array}{l}\text { \% Report- } \\
\text { ing AEs }\end{array}$ & $\begin{array}{l}\text { Most commonly } \\
\text { reported } \\
\text { minor AEs }\end{array}$ & $\begin{array}{l}\text { Most commonly } \\
\text { reported } \\
\text { major AEs }\end{array}$ \\
\hline Manipulation & $15.8(24)$ & $\begin{array}{l}\text { Pain (13) } \\
\text { Fatigue (2 } \\
\text { Dizziness (3) }\end{array}$ & $15.4(71)$ & Aggravation (65) & $\begin{array}{l}\text { Fractures (3) } \\
\text { Nerve damage (2) } \\
\text { Disk protrusion (1) }\end{array}$ \\
\hline Acupuncture & $12.5(23)$ & $\begin{array}{l}\text { Aggravation (6) } \\
\text { Mental effects (3) } \\
\text { Fatigue (3) } \\
\text { Pain (2) } \\
\text { Needle trauma (2) }\end{array}$ & $<0.1(4)$ & $\begin{array}{l}\text { Aggravation (2) } \\
\text { Visual } \\
\text { disturbance (1) }\end{array}$ & Septic arthritis (1) \\
\hline Homeopathy & $9.8(28)$ & $\begin{array}{l}\text { Aggravation (11) } \\
\text { Mental effects (3) } \\
\text { Digestive effects(2) }\end{array}$ & $<0.1(9)$ & $\begin{array}{l}\text { Aggravation (5) } \\
\text { Eye infection (1) } \\
\text { Skin rash (1) }\end{array}$ & $\begin{array}{l}\text { Liver failure (1) } \\
\text { Anaphylaxis (1) }\end{array}$ \\
\hline $\begin{array}{l}\text { Herbal } \\
\text { medicine }\end{array}$ & $7.6(10)$ & Digestive effects (3) & $<0.1(6)$ & $\begin{array}{l}\text { Aggravation (2) } \\
\text { Rashes (2) } \\
\text { Nausea (1) }\end{array}$ & Liver toxicity (1) \\
\hline
\end{tabular}

Numbers in parentheses show absolute number of cases.

cy and safety of these therapies. It is commonly believed that complementary/ alternative medicine (CAM) is natural and therefore safe and that people can be treated without side-effects. The results of two recent surveys, however, provide evidence on the potential risks.

In the first study, we invited readers of the British daily newspaper The Guardian (circulation about 500,000) to answer a questionnaire about their experiences with CAM. The 386 respondents were, as expected, strongly in favour of its use: $91.4 \%$ had a positive attitude, and $95.6 \%$ said it had improved their quality of life. But when asked about treatment outcome, a large proportion $(23.8 \%)$ reported adverse effects (AE) (see table). The rate of AEs following acupuncture $(12.5 \%)$ was similar to that reported elsewhere ${ }^{2}$.

In the second study, a questionnaire was sent to every general practice in Devon and Cornwall $(n=972)$ enquiring whether general practitioners (GPs) had encountered patients experiencing problems with complementary terapies. Of the respondents, $176 \quad(38.2 \%)$ reported encountering AEs. The table describes the direct physical AEs, but there were also 11 reports of psychological effects (mainly disillusion at absence of promised benefit) and 17 cases of inappropriate management or frank misdiagnosis by complementary therapists. Manipulation therapy, such as chiropractic and osteopathy, was the dominant cause of physical AEs seen by GPs (see table): 3 of these cases (1.3\% of all AEs reported) led to bone fractures and 2 to neurological ence of serious AEs. The GP survey, on the other hand, was likely to collect reports of the more severe AEs. Furthermore, neither questionnaire provides reliable prevalence figures. However, both sets of data illustrate that CAM is not entirely free of risk. We therefore suggest more rigorous investigations into this topic to determine the extent of the problem and (if necessary) to design a strategy to minimize harm.

N. C. Abbot

\section{A. R. White}

E. Ernst

Postgraduate Medical School,

University of Exeter,

25 Victoria Park Road,

Exeter EX2 4NT,

e-mailE.Ernst@exeter.ac.uk 1. MacLennan, A.H., Wilson, D.H. \& Taylor, A.W. Lancet 347,
569-573 (1996).

2. Norheim, A.J. \& Fonebo, V. Lancet 345, 1576 (1995).

\section{Feynman faux pas}

SIR - Our fascination with Richard Feynman's lectures (see review of Feynman's Lost Lecture ${ }^{1}$ ) is fuelled in part by the glimpses they give us of his extraordinary mind. Readers of Nature might therefore relish learning that Feynman could blunder.

In a lecture at the US National Academy of Sciences in 1955 (reprinted in ref. 2), Feynman muses about why writers and artists do not rhapsodize about science. He wonders if perhaps they don't know "how to read the music", which he suggests is necessary to develop beautiful abstract ideas. $\mathrm{He}$ then invents an example in which ironically he, of all people, appears to misread the music. Feynman says (page 244): "For instance, the scientific article may say, "The radioactive phosphorus content of the cerebrum of the rat decreases to one-half in a period of two weeks.' Now what does that mean? It means that phosphorus that is in the brain of a rat - and also in mine and yours - is not the same phosphorus as it was two weeks ago."

He tries to make something of the fact that our mind retains information despite replacement of phosphorus atoms in the brain. But the example he gives would not prove replacement; in fact, it suggests quite the opposite. In an endearing lapse, Feynman appears to have blanked out on the half-life for the decay of ${ }^{32} \mathrm{P}$ to sulphur, which just happens to be two weeks; if the radioactivity decreases to one-half in two weeks it means (within experimental error) that there was no turnover of phosphorus in the cerebrum.

A further irony is that the excerpt is cited approvingly by Daniel C. Dennett in his much-praised book on evolution ${ }^{3}$; Dennett is also concerned about scientific abstraction and introduces the quotation with reckless adulation, saying (page 360), "Nobody has ever put it better than the physicist Richard Feynman".

Irwin Tessman

Department of Biological Sciences,

Purdue University,

West Lafayette, Indiana 47907, USA

1. Murdin, P. Nature 380, 680 (1996).

2. Feynman, R. What Do You Care What Other People Think? (Norton, New York, 1988).

3. Dennett, D. C. Darwin's Dangerous Idea (Simon \& Schuster, New York, 1995).

\section{Hard evidence}

SIR - It has been suggested that the problem of consciousness consists of an 'easy problem' and a 'hard problem'. Exploring the neurobiology of vision, for example, is 'easy' but understanding subjective visual experience is 'hard"1-3. To solve the hard problem, a 'new theory' has been developed in which 'conscious experience' is an irreducible phenomenon, with a physical (brain state) and an experiential (subjective state) aspect linked by psychophysical laws ${ }^{3}$. Replace 'conscious experience' with 'unbewusster Schluss' and this is the theory presented by von Helmholtz in 1857 (ref. 4). Progress in the study of consciousness has not been delayed by theoretical constraints.

\section{Per Sødersten}

Karolinska Institute,

Department of Clinical Neuroscience,

Novum, S-141 57 Huddinge,

Sweden

1. Nature 381, 97 (1996).

2. Koch, C. Nature 381, 123-124 (1996)

3. Chalmers, D. J. Sci. Am. 62-68 (December 1995).

4. von Helmholtz, H. Handbuch der Physiologischen Optik

in Allgemeine Encyclopädie der Physik, Vol. 9 (eds Brix, P. W. et al.) (Voss, Leipzig, 1857-62) 